\title{
Trade Mark Specifications: Clear (AND Precise) SkiES AHEAD?
}

The majority of trade mark law cases decided by the Court of Justice of the European Union (CJEU) have been about the "sign" that is registered as a trade mark. Less guidance has been provided regarding the "specification" of the goods or services in respect of which the mark is registered and confers protection. Sky v Skykick (Case C371/18, ECLI:EU:C:2020:45), one of the most anticipated trade mark cases in recent years, gave the CJEU the opportunity to answer important questions on the latter.

The well-known British broadcasting and telecommunications company Sky holds numerous EU and UK Trade Marks consisting of the word "SKY" (the Trade Marks). Each of the Trade Marks is registered in respect of numerous classes of goods and services following the internationally agreed Nice Classification system. The specifications cover all manner of goods and services, including the core areas of Sky's business, but also going well beyond this - included in the lengthy lists are items as farflung as whips, bleaching preparations, and Gladstone bags.

The defendant company group, Skykick, is a start-up business which offers cloud migration services. Sky brought proceedings in the High Court of England and Wales claiming that Skykick's use of the sign "Skykick" and variants thereof constituted passing off and infringed the Trade Marks, relying on the fact that its registrations cover, inter alia, "computer software" (Class 9), "telecommunications services" (Class 38), and "electronic mail services" (Class 38). Skykick denied these claims, and counterclaimed that the Trade Marks were wholly or partially invalid.

Arnold J (as he then was) delivered the main High Court judgment ([2018] EWHC 155 (Ch)). Sky's passing off claim was dismissed (at [356]). The infringement claim was, however, more complicated because Skykick's counterclaims required answers to two unresolved issues of European trade mark law.

First, Skykick claimed the Trade Marks were partially invalid because the specifications relied on by Sky, which included broad terms such as "computer software", lacked sufficient clarity and precision. This contention was based on Chartered Institute of Patent Attorneys $v$ Registrar of Trade Marks (IP TRANSLATOR) (Case C-307/10, ECLI:EU:C:2012:361) (now incorporated into Article 33(2) of Regulation (EU) 2017/1001 (OJ 2017 L 154 p. 1)), where the CJEU ruled that, at the application stage, the trade mark must specify the goods and services for which registration is sought with sufficient clarity and precision to determine the extent of protection to be conferred by the mark. The difficulty for Skykick was that its argument relied on lack of clarity and precision being a ground for invalidating a registered trade mark, despite this not being listed in the absolute grounds for invalidity in the relevant legislation (Articles 7(1) and 51(1) of Regulation (EC) 40/94 (OJ 1994 L 11 p. 1) and Article 3 of Directive (EEC) 89/104 (OJ 1989 L 40 p. 1), which are the predecessors of Articles 7(1) and 59(1) of Regulation 2017/1001 and Article 4(1) of Directive (EU) 2015/2436 (OJ 2015 L 336 p.1)).

Second, Skykick argued that the Trade Marks should be invalidated because they were registered in bad faith. On the facts, Arnold $\mathbf{J}$ concluded that Sky did not intend to 
use the Trade Marks for all goods and services covered by the specifications. While Sky was clearly using the Trade Marks for some of the goods and services specified and had future plans for some further goods, its strategy was one of seeking very broad protection regardless of whether it was commercially justified (at [250]). What the existing case law left uncertain, however, was the legal effect of this finding. In particular, does lack of intention to use a trade mark in relation to specified goods and services constitute bad faith and, if so, is the mark wholly or just partially invalid?

The two issues outlined above were referred to the CJEU for a preliminary ruling. In his Opinion, Advocate-General Tanchev billed the request as legally significant, because it would allow the CJEU to determine the extent to which trade mark law will protect the interests of trade mark proprietors. If Skykick were unable to defend the infringement proceedings, it would signal that trade mark law “...grants the trade mark proprietor a position of absolute monopoly...in spite of the fact that the mark has not been used, and is not likely to be used, for many of the goods and services in respect of which it was registered" (ECLI:EU:C:2019:864 at [5]). Despite this, the CJEU delivered a narrow judgment, presenting its answers as a relatively straightforward application of existing principles.

On the first issue, the CJEU unsurprisingly held that the absolute grounds are exhaustive (at [58]), and consequently that lack of clarity and precision of the specification is not a ground for invalidating a registered trade mark. On this point, the CJEU agreed with A-G Tanchev. But it also went further. While A-G Tanchev had found that lack of clarity and precision could mean a mark was "contrary to public policy" (which is an enumerated ground for invalidity), the CJEU said that the concept of public policy in trade mark law does not cover characteristics of the trade mark application itself (at [66]). No prior cases or reasons were provided in support of this conclusion, though it is consistent with the fact that public policy has only been invoked in limited situations, for example, in relation to "symbols of despotism" deemed offensive in a particular country (see Case T-232/10, Couture Tech Ltd $v$ OHIM ECLI:EU:T:2011:498).

One can wonder, though, why the public policy ground is not sufficiently capacious to deal with situations where a specification is excessively broad, especially as it is the ground which most neatly captures the difficulties with registrations using terms like "computer software". Arnold J's reasoning in the main judgment seems to support precisely this point. For him, the problem with "computer software" is not so much that it lacks clarity and precision. The real issue is that this registration "...is unjustified and contrary to the public interest because it confers on the proprietor a monopoly of immense breadth which cannot be justified by any legitimate commercial interest of the proprietor" (at [171]). Understood in this way, the difficulty for Skykick might be that it wrongly pleaded the case from the outset as being about lack of clarity and precision, and that it could perhaps have had more success in the High Court if it ran a novel argument by directly seeking invalidation on public policy grounds. But where the CJEU judgment seems to leave us is a broader confirmation that public policy is a relatively blunt tool in trade mark law, only available in narrow circumstances.

Regarding the second issue, the CJEU drew on its decision in Koton $v$ EUIPO (Case C-104/18 P, ECLI:EU:C:2019:724), holding that the bad faith ground applies where there is evidence that the application was filed, not with the goal of engaging fairly in 
competition, but with the intention of either: (i) dishonestly undermining the interests of third parties; or (ii) obtaining exclusive rights for purposes other than those falling within the functions of a trade mark (at [75]). The CJEU was clear that, at the time of filing, an applicant need not know precisely how they will use a mark, nor do they need to have economic activity corresponding to the specification. Moreover, where bad faith is established in relation to certain goods and services, it will be a basis for invalidity for those goods and services only (at [80]).

Following the CJEU's decision, Arnold LJ delivered a further High Court judgment applying the rulings ([2020] EWHC 990 (Ch)). After swiftly dismissing Skykick's counterclaim regarding lack of clarity and precision (at [12]), Arnold LJ turned to bad faith. Sky's applications were held to be partly in bad faith as its intention was “...obtaining an exclusive right for purposes other than those falling within the functions of a trade mark, namely purely as a legal weapon against third parties..." (at [21]). Accordingly, Arnold LJ revised the scope of some specifications like "computer software" to reflect the extent of the bad faith proved. But this was not sufficient to save Skykick from Sky's infringement claim. Ultimately, a technical point became crucial. Skykick had not specifically alleged bad faith for certain goods and services on which Sky's infringement claim relied, including "electronic mail services" (at [14]). To this extent, therefore, the Trade Marks remained valid (at [37]). An infringement finding followed because Skykick's email migration service was identical to "electronic mail services" and there was a likelihood of confusion (at [39]).

On one view, Arnold LJ's decision on partial invalidity signals to brand owners that, under the CJEU's bad faith test, specifications like "computer software" might not be tolerated. But whether this does enough to deter companies from filing broad specifications or, once registered, from using trade marks purely as a "legal weapon" is questionable. In this case, the factual findings against Sky were serious, revealing a deliberate strategy of making trade mark applications so that they could subsequently be wielded against third parties in threatened or actual legal proceedings. However, the only consequence flowing from this conduct was that its registrations were eventually whittled down in court insofar as bad faith could be proved. Time will tell whether this continues to be the approach taken in bad faith cases. From a UK perspective, the CJEU judgment binds domestic courts and tribunals for the time being, despite the UK's withdrawal from the EU. However, the position could well change in the future pursuant to the European Union (Withdrawal) Act 2018, s. 6 (as amended by the European Union (Withdrawal Agreement) Act 2020, s. 26), especially if bad faith is considered by the Supreme Court.

\section{JEEVAN HARIHARAN}

Address for Correspondence: Faculty of Laws, University College London, Bentham House, 4-8 Endsleigh Gardens, London, WC1H 0EG, UK. Email: jeevan.hariharan.19@ucl.ac.uk. 